\title{
Front Matter: Volume 7884
}

, "Front Matter: Volume 7884," Proc. SPIE 7884, Lasers in Dentistry XVII, 788401 (18 March 2011); doi: 10.1117/12.890181

SPIE. Event: SPIE BiOS, 2011, San Francisco, California, United States 


\section{PROGRESS IN BIOMEDICAL OPTICS AND IMAGING}

Vol. 12, No. 2

\section{Lasers in Dentistry XVII}

Peter Rechmann

Daniel Fried

Editors

23 January 2011

San Francisco, California, United States

Sponsored and Published by

SPIE

Volume 7884

Proceedings of SPIE, 1605-7422, v. 7884

SPIE is an international society advancing an interdisciplinary approach to the science and application of light. 
The papers included in this volume were part of the technical conference cited on the cover and title page. Papers were selected and subject to review by the editors and conference program committee. Some conference presentations may not be available for publication. The papers published in these proceedings reflect the work and thoughts of the authors and are published herein as submitted. The publisher is not responsible for the validity of the information or for any outcomes resulting from reliance thereon.

Please use the following format to cite material from this book:

Author(s), "Title of Paper," in Lasers in Dentistry XVII, edited by Peter Rechmann, Daniel Fried, Proceedings of SPIE Vol. 7884 (SPIE, Bellingham, WA, 2011) Article CID Number.

ISSN $1605-7422$

ISBN 9780819484215

Published by

SPIE

P.O. Box 10, Bellingham, Washington 98227-0010 USA

Telephone +1 3606763290 (Pacific Time) · Fax +1 3606471445

SPIE.org

Copyright @ 2011 , Society of Photo-Optical Instrumentation Engineers.

Copying of material in this book for internal or personal use, or for the internal or personal use of specific clients, beyond the fair use provisions granted by the U.S. Copyright Law is authorized by SPIE subject to payment of copying fees. The Transactional Reporting Service base fee for this volume is $\$ 18.00$ per article (or portion thereof), which should be paid directly to the Copyright Clearance Center (CCC), 222 Rosewood Drive, Danvers, MA 01923. Payment may also be made electronically through CCC Online at copyright.com. Other copying for republication, resale, advertising or promotion, or any form of systematic or multiple reproduction of any material in this book is prohibited except with permission in writing from the publisher. The CCC fee code is 1605$7422 / 11 / \$ 18.00$.

Printed in the United States of America.

Publication of record for individual papers is online in the SPIE Digital Library.

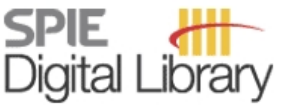

SPIEDigitalLibrary.org

Paper Numbering: Proceedings of SPIE follow an e-First publication model, with papers published first online and then in print and on CD-ROM. Papers are published as they are submitted and meet publication criteria. A unique, consistent, permanent citation identifier (CID) number is assigned to each article at the time of the first publication. Utilization of CIDs allows articles to be fully citable as soon they are published online, and connects the same identifier to all online, print, and electronic versions of the publication. SPIE uses a six-digit CID article numbering system in which:

- The first four digits correspond to the SPIE volume number.

- The last two digits indicate publication order within the volume using a Base 36 numbering system employing both numerals and letters. These two-number sets start with 00, 01, 02, 03, 04 , 05, 06, 07, 08, 09, 0A, OB ... 0Z, followed by 10-1Z, 20-2Z, etc.

The CID number appears on each page of the manuscript. The complete citation is used on the first page, and an abbreviated version on subsequent pages. Numbers in the index correspond to the last two digits of the six-digit CID number. 


\section{Contents}

vii Conference Committee

\section{LASERS IN ENDODONTICS AND ORTHODONTICS}

788402 Diode laser for endodontic treatment: investigations of light distribution and disinfection efficiency [7884-01]

K. Stock, R. Graser, M. Udart, A. Kienle, R. Hibst, Univ. Ulm (Germany)

788403 Laser scanning dental probe for endodontic root canal treatment [7884-02]

M. A. B. Blank, M. Friedrich, J. D. Hamilton, P. Lee, J. Berg, E. J. Seibel, Univ. of Washington (United States)

788404 Influence of Tm:YAP laser irradiation on tensile strength for bracket debonding [7884-03] T. Dostalova, Charles Univ. in Prague (Czech Republic); H. Jelinkova, J. Sulc, P. Koranda, M. Nemec, M. Fibrich, M. Jelinek, Czech Technical Univ. in Prague (Czech Republic); P. Michalik, Charles Univ. in Prague (Czech Republic); M. Miyagi, Sendai National College of Technology (Japan)

\section{LASERS IN CALCULUS DETECTION}

788405 Fluorescence-based calculus detection using a 405-nm excitation wavelength [7884-04] O. Brede, F. Schelle, S. Krueger, B. Oehme, C. Dehn, M. Frentzen, A. Braun, Univ. Dental Clinic Bonn (Germany)

788406 Detection of calculus by laser-induced breakdown spectroscopy (LIBS) using an ultra-short pulse laser system (USPL) [7884-05]

F. Schelle, O. Brede, S. Krueger, B. Oehme, C. Dehn, M. Frentzen, A. Braun, Univ. Dental Clinic Bonn Germany)

788407 Dental calculus image based on optical coherence tomography [7884-06]

Y.-S. Hsieh, National Chiao-Tung Univ. (Taiwan); Y.-C. Ho, S.-Y. Lee, National Yang-Ming Univ. (Taiwan) and Taipei Veterans General Hospital (Taiwan); C.-C. Chuang, National Taiwan Univ. (Taiwan); C.-Y. Wang, National Chiao-Tung Univ. (Taiwan); C.-W. Sun, National Yang-Ming Univ. (Taiwan) and National Chiao-Tung Univ.

\section{DENTAL HARD TISSUE AND EARLY CARIES IMAGING I}

7884 OA Thermophotonic lock-in imaging: a novel early caries detection and imaging modality [7884-09]

N. Tabatabaei, A. Mandelis, Univ. of Toronto (Canada); B. T. Amaechi, The Univ. of Texas Health Science Ctr. at San Antonio (United States) 
$7884 \mathrm{OB} \quad$ In vivo near-IR imaging of occlusal lesions at $1310 \mathrm{~nm}$ [7884-10]

D. Fried, M. Staninec, C. L. Darling, C. Lee, H. Kang, K. H. Chan, Univ. of California, San

Francisco (United States)

DENTAL HARD TISSUE AND EARLY CARIES IMAGING II

7884 OC Swept source optical coherence tomography for quantitative and qualitative assessment of dental composite restorations [7884-11]

A. Sadr, Y. Shimada, Tokyo Medical and Dental Univ. (Japan); J. R. Mayoral, Univ. Internacional de Catalunya (Spain); I. Hariri, T. A. Bakhsh, Tokyo Medical and Dental Univ. (Japan); Y. Sumi, National Ctr. for Geriatrics and Gerontology (Japan); J. Tagami, Tokyo Medical and Dental Univ. (Japan)

7884 OD Development of polarization dental imaging modality and evaluation of its clinical feasibility [7884-12]

E. Kim, T. Son, Y. Bae, B. Jung, Yonsei Univ. (Korea, Republic of)

$7884 \mathrm{OE} \quad$ A construction of standardized near infrared hyper-spectral teeth database: a first step in the development of reliable diagnostic tool for quantification and early detection of caries [7884-13]

M. Bürmen, P. Usenik, A. Fidler, Univ. of Ljubljana (Slovenia); F. Pernuš, B. Likar, Univ. of Ljubljana (Slovenia) and Sensum (Slovenia)

7884 OF Cross-sectional imaging of extracted jaw bone of a pig by optical coherence tomography [7884-14]

N. Tachikawa, Tokyo Medical and Dental Univ. (Japan); R. Yoshimura, K. Ohbayashi, Kitasato Univ. (Japan)

7884 OG Enhancing caries resistance in occlusal fissures with a short-pulsed $\mathrm{CO}_{2} 9.6 \mu \mathrm{m}$ laser: an in vitro pH-cycling study, preliminary results [7884-15]

D. Charland, Univ. of California, San Francisco (United States); C. Fulton, National Research Council Canada (Canada); B. Rechmann, Univ. of California, San Francisco (United States); M. Hewko, National Research Council Canada (Canada); J. Featherstone, Univ. of California, San Francisco (United States); L.-P. Choo-Smith, National Research Council Canada (Canada); P. Rechmann, Univ. of California, San Francisco (United States)

\section{LASER EFFECTS ON HARD TISSUES}

$7884 \mathrm{OH} \quad$ Spectroscopic analysis of both enamel and dentin surfaces following $\mathrm{XeCl}$ excimer laser surface treatment [7884-16]

Y. Badr, M. Gheith, Cairo Univ. (Egypt)

7884 Ol High-power, diode-dumped Er:YAG for dentistry [7884-17]

C. Hagen, Pantec Engineering AG (Liechtenstein); A. Heinrich, Pantec Biosolutions AG

(Liechtenstein); B. Nussbaumer, Pantec Engineering AG (Liechtenstein) 
$78840 \mathrm{~J} \quad$ Heat generation caused by ablation of dental restorative materials with an ultra short pulse laser (USPL) system [7884-18]

A. Braun, R. Wehry, O. Brede, M. Frentzen, F. Schelle, Univ. Dental Clinic Bonn (Germany)

7884 OK Etching of enamel for direct bonding with a thulium fiber laser [7884-19]

A. S. Kabaş; Sarp, M. Gülsoy, Bogaziçi Univ. (Turkey)

$7884 \mathrm{OL}$ Selective treatment of carious dentin using a mid-infrared tunable pulsed laser at $6 \mu \mathrm{m}$ wavelength range [7884-20]

M. Saiki, K. Ishii, Osaka Univ. (Japan); K. Yoshikawa, K. Yasuo, K. Yamamoto, Osaka Dental Univ. Hospital (Japan); K. Awazu, Osaka Univ. (Japan), Univ. of Fukui (Japan), and Kyoto Univ. (Japan)

\section{POSTER SESSION}

$7884 \mathrm{OM}$ An optical method for the analysis of the exitance diffused by light-transmitting fiber post [7884-21]

S. Cattini, L. Rovati, Univ. of Modena and Reggio Emilia (Italy)

788400 Polarization resolved near-IR imaging of sound and carious dental enamel [7884-24]

C. L. Darling, K. H. Chan, D. Fried, Univ. of California, San Francisco (United States)

$78840 Q \quad$ Repair of artificial lesions using an acidic remineralization model monitored with cross-polarization optical coherence tomography [7884-26]

H. Kang, C. L. Darling, D. Fried, Univ. of California, San Francisco (United States)

7884 OR Selective removal of dental composite using a rapidly scanned carbon dioxide laser [7884-27]

K. H. Chan, D. Fried, Univ. of California, San Francisco (United States)

7884 OS Adhesion studies on dental enamel surfaces irradiated by a rapidly scanned carbon dioxide laser [7884-28]

K. K. Chang, M. Staninec, K. H. Chan, D. Fried, Univ. of California, San Francisco (United States)

7884 OU Photoacoustic microscopy of human teeth [7884-30]

B. Rao, X. Cai, C. Favazza, J. Yao, L. Li, Washington Univ. in St. Louis (United States);

S. Duong, L. Liaw, J. Holtzman, P. Wilder-Smith, Beckman Laser Institute and Medical Clinic

(United States); L. V. Wang, Washington Univ. in St. Louis (United States)

$7884 \mathrm{OV}$ Cross polarization optical coherence tomography for diagnosis of oral soft tissues [7884-31]

N. Gladkova, M. Karabut, E. Kiseleva, Nizhny Novgorod State Medical Academy (Russian Federation); N. Robakidze, Saint-Petersburg Medical Academy of Postgraduate Studies (Russian Federation); A. Muraev, J. Fomina, Nizhny Novgorod State Medical Academy (Russian Federation)

7884 oW The impact of laser irradiation during antimicrobial photodynamic therapy in an artificial biofilm model [7884-32]

M. Schneider, Univ. Dental Clinic Bonn (Germany); G. Kirfel, Univ. of Bonn (Germany);

M. Berthold, O. Brede, M. Frentzen, A. Braun, Univ. Dental Clinic Bonn (Germany) 
$78840 X \quad$ Near infrared imaging of teeth at wavelengths between 1200 and $1600 \mathrm{~nm}$ [7884-33]

S. Chung, D. Fried, M. Staninec, C. L. Darling, Univ. of California, San Francisco (United States)

Author Index 


\title{
Conference Committee
}

\author{
Symposium Chairs
}

James G. Fujimoto, Massachusetts Institute of Technology (United States)

R. Rox Anderson, Wellman Center for Photomedicine, Massachusetts General Hospital, Harvard School of Medicine (United States)

Program Track Chair

Brian Jet-Fei Wong, Beckman Laser Institute and Medical Clinic (United States)

Conference Chairs

Peter Rechmann, University of California, San Francisco (United States)

Daniel Fried, University of California, San Francisco (United States)

Program Committee

Gregory B. Altshuler, Palomar Medical Technologies, Inc.

(United States)

Tatjána Dostálová, Charles University in Prague (Czech Republic)

John D. Featherstone, University of California, San Francisco (United States)

David M. Harris, Bio-Medical Consultants, Inc. (United States)

Harvey A. Wigdor, Advocate Illinois Masonic Medical Center (United States)

Session Chairs

1 Lasers in Endodontics and Orthodontics

Daniel Fried, University of California, San Francisco (United States)

2 Lasers in Calculus Detection

Daniel Fried, University of California, San Francisco (United States)

3 Lasers in Periodontology

Daniel Fried, University of California, San Francisco (United States)

4 Dental Hard Tissue and Early Caries Imaging I

Daniel Fried, University of California, San Francisco (United States) 
5 Dental Hard Tissue and Early Caries Imaging II

Peter Rechmann, University of California, San Francisco (United States)

6 Laser Effects on Hard Tissues

Peter Rechmann, University of California, San Francisco (United States) 